\title{
The Modern and the Traditional African Women and Colonial Morality
}

\author{
Rabah Omer (Corresponding author) \\ United States \\ E-mail: rabahomer@yahoo.com
}

Received: June 13, 2017 Accepted: August 2, 2017 Published: June 24, 2018

doi:10.5296/ijch.v5i1.13311 URL: https://doi.org/10.5296/ijch.v5i1.13311

\begin{abstract}
The meanings of modernity have radically shifted over time, yet interestingly, the modern continues to be the modern and the traditional is still the traditional. I address this observation by asking: what is the modern and what is the traditional, how are they identified, by whom, when and according to what premises? I examine one cultural component: women and sexual morality. I focus on women-men relationships, dress, and dance to examine as cultural themes. I focus on African women and colonial morality and I bring examples across different eras and and different regions to discuss the contours of the changing notion of modernity. The signs of modernity have been inconsistent over time and across regions but modernity have always been consistent on particular features that makes it a fluid biased concept.
\end{abstract}

"As Roman imperialism laid the foundations of the modern civilization, and led the wild barbarians of these islands along the path of progress, so in Africa today we are repaying the debt, and bringing to the dark places of the earth, the abode of barbarism and cruelty, the torch of culture and progress, while ministering to the material needs of our own civilization... We hold these countries because it is the genius of our race to colonize, to trade, and to govern" (Lord Lugard,1922) .

\section{Introduction}

Modernity and tradition are used as contradictory and exclusive concepts where the former

${ }^{1}$ Colonial Desire: Hybridity in Theory, Culture and Race by Robert J.c Young. 
indicates progress and the latter indicates a past without contemporary legitimacy. Modernity characteristically denotes a post-traditional, post-medieval historical period, one marked by the transition from feudalism and agrarian structure to capitalism, industrialization, secularization, rationalization, the nation-state and its institutions with their systems of surveillance (Barker 2005, 444). Conceptually, however, modernity refers to the modern era. For a while in the eighteenth century, culture was used as equivalent of civilization in a sense established by Enlightenment historians. The "natives" were perceived to not have culture at all. Then that notion was challenged by anthropologists and the word "culture" was used as an alternative to express other kinds of human development and variable cultures of different peoples in different periods of time. Civilization was used in Europe to express the triumph of modernity where the modern world recognized itself as better than antiquity.

At the time, Europe came at encounter with other cultures it continued to describe itself as civilized and modern but in contrast not only to antiquity but to other cultures as well. Thus, Europe created the concept of savageness and barbarism as antithesis to its modernity and civilization. Hencefoth, Europe was to represent the modern model and the rest was to represent the antiquity; the traditional. Accordingly, the modern model, that is Europe, embarked on missions of civilizing and modernizing the traditional; that is the rest of the world in which Africa is "the most traditional;" the most backward.

These labels continued to exist where the modern remained the modern and the traditional remained the traditional in a curious way despite the shifts and changes that happened on the meaning and signs of modernity. In this essay, I would like to address this observation by asking: what is the modern and what is the traditional, how are they identified, by whom, when and according to what premises?

I address this broad question by examining one cultural component: women and sexual morality. I choose this topic in particular because women's sexual morality is often connected to freedom and progress whether in religious, political, or cultural theories. In modernity, women liberation and empowerment is a major theme where women's rights are used as a measure of progress. To grasp these issues I focus on women-men relationships, dress, and dance to examine as cultural themes.

In the first section I will examine women morality in Europe to understand the moral ground on which Europe perceived and judged women in Africa. In the second section I choose dress as an interesting topic that signals people's belief systems and morality. In the third section I examine dance as a cultural feature that indicates the cultural values and moral views of its society. In the conclusion I discus the observed patterns of modernity according to which the traditional is defined. I cite examples across time and geographies to discuss contours of the notion of modernity.

\section{Women and Morality in Colonial Europe}

It is known that colonialism was declared as a civilizing mission in which political forces joined religious missionaries to bring the light of progress to the "dark continent." The civilizing mission targeted both the moral and material conditions of its subjects. Civilizing 
the subjects morally was to introduce the European values to the African people. During colonialism, introducing "European values" meant specifically introducing European bourgeois values as it has been indicated by many scholars when tracing the formation of theories of race. According to some scholars, racial theories were embedded in the making of class identity in European societies. Foucault, for instance, explains the economic processes and political structure in which the decline of absolutism and monarchy and the rise of liberalism, commitment to "freedom" and modernity undermined social hierarchies based on descend and called for new ways of naturalizing the inequities on which the emergent bourgeois order was based.

According to many scholars, including Foucault and Stoler, sexuality was a major moral issue and measure of class identity. Foucault, for instance, suggests that earliest technologies of sex arose around the eighteenth century around the political economy of population, regulating the modes of sexual conduct by which populations could be expanded and controlled. Sex, according to Foucault and others, was the tool for surveillance of individual's morality where the bourgeois were considered the most virtuous class whiles the poor lacked morality. Accordingly, modernity, was a process in which the older codes of legitimacy were replaced by a system of power in which individual's sexuality was scrutinized and controlled to maintain class identity and population control.

Although scholars debate the processes and the dates of developing theories and practices of race, it is agreed that in the eighteenth century it became the codes of colonial order in which modernity, the civilizing mission, and the "measure of man" were formed. For instance, Stoler argues that the assertion, of bourgeois order and morality was never distinct from the changing definition of who was European; cultural appropriateness and sexual practices secured racial identities(Stoler,1996).

Hence, we could argue that racism and the control over individual's sexuality were necessarily linked to "modernity" as identified by European colonial powers. The individual's sexual practices signaled her level of morality and granted her the respectability required by modernity if these practices showed restrain and control. This notion was projected on colonial subjects to signify their level of need of modernity. For example, as Stoler, in Race and the Education of Desire, points out that the discursive management of the sexual practices of colonizer and colonized was fundamental to the colonial order of things. She elaborates that "the discourses of sexuality at once classified colonial subjects into distinct human kinds while policing the domestic recesses of imperial rule"(Stoler,1996:4). This indicates that sexual practices signaled "others' " level of morality and classified them accordingly on the ladder of civilization on which Europeans were on the top. If colonial Europe considered itself modern, that is sexually virtuous and "appropriate", others would be immoral sexual beings and Africans were the most eroticized and described as promiscuous and shameless.

The focus on sexuality guided bourgeois morality in Europe was directed squarely towards women where their bodies were politicized and moralized. They were considered the bearers of more racist imperial order. For example, the Dutch and English women were not allowed 
to emigrate because it was feared that they would bring "shame to the nation" and disgrace to all Christian nations if they bedded with non-White men(Stoler,1996).

Thus men's sexual anxiety was not only about their own desire but also about controlling women's sexuality. We notice that this obsession with sexuality had different motivations during colonial era. In the seventeenth century it was motivated by the notion of "Christian nation" in which it was a matter of religious teaching to repress and scandalize sexuality. And in the nineteenth century it was motivated by the notion of bourgeois respectability. Nonetheless, the indicated obsession by women's sexuality was a shared feature in both bourgeois and Christian notions. It is needless to say that this control over women sexuality could not possibly be only about sex without other gender-based implications such as lack of social independence and inferior cultural status. This point is important to mention because it indicates the meaning of "liberating" African women claimed by colonial agents and their civilizing mission as will be discussed later.

Therefore, in colonial discourses, sexuality, women, and the way they dressed or behaved were heavily addressed in describing the savageness of the subjects or/and in forging the ways of "civilizing" them. For instance, in The Races of Europe, William Z. Ripley argues that "one of the most subtle physiological effects of a tropical climate is a surexcitation of sexual organs, which in the presence of a native servile morally underdeveloped population often leads to excesses even at a tender age" (emphasis is mine) (Young,1995:150). Also In History of Jamaica, Edward Long states "African women are libidinous and shameless as monkeys, or baboons...in fact they admit these animals frequently to their embrace"(Young,1995:150-151). Obviously, such descriptions were primarily informed by and rooted in religious morality where codes of ethics were outlined by Christian teachings as Richard wrote in 1940 Richard that "Christian sex ethic was to many Africans the chief content of Christian teachings, since it is by largely keeping or failing to keep the Christian sex codes that the convert wins or loses membership of the church"(Chanock,1998:155). Accordingly, colonial agents made it their task to halt practices of the past and bring modernity which was directed squarely towards controlling African women and their sexuality.

\section{Women and Sexual Morality in Africa}

In "Law Custom and Social Order: The Colonial Expereince in Malawi and Zimbabwe," Chanock indicates that white people, during colonialism, severely condemned Africans sexual morality and women status; they were considered to have no sexual morals at all. For example, Lomwe people of central Africa were described: "their morality so low adultery was not considered an offense." It was also reported about the women of the Mang'anja: "the chastity of women or their feelings on the subject (if they have any) is not considered; it is their customs to occasionally change wives." Also, Fort Johnson reported that "between the Mvera and Monkey bay no man dare trust his wife." Smith and Dale also wrote about the Ilan "how fragile the marriage bond is... women are bandied from man to man; and of their own accord leave one husband to another. It is not unusual a woman scarcely out of her teens to have had four or five husbands still living." Also, Reverend Guillaime observed of the Bemba 
"for the smallest reason woman quitted her husband's house." Additionally, officials in Northern Rhodesian government were concerned that "parents allowed their daughters far greater freedom." So the white man's mission appeared to be both the "liberation" of women and the "improvement of morals." (Chanock, 1996: 145-159).

Accordingly, one of the ways by which African marriage and sex practices were addressed was to give men more control over women's sexuality. This view was, of course, informed, as mentioned before, by bourgeois morality and commitment to modernity. For instance, in 1907 Judge Griffin in Malawi states in evaluating the effects of colonial policies introduced on marriage laws and practices that "a native looks upon all infractions of his marriage contract ..as serious wrong which he is quick to resent and punish, and I am strongly of the opinion that every assistance should be given for the maintenance of the security of his domestic rights." Also, as a measure of control over women's sexuality, the colonial court did not acknowledge any case brought without "evidence of legal marriage" according to Christian rules. Those bonds which did not submit to marriage were considered "immoral connection" and any redress made by court is "to uphold immorality." African unions, in the eyes of colonial agents, "declined the morals of women" because of the the freedom it allowed to them. Furthermore, the Northern Rhodesian courts, to forge a law against the "frivolous girls" they worked on controlling their sexual behavior by giving much authority to the "controllers of the society" referring to "headmen and the young men" (Chanock, 1996). Thus, improving women morality according to colonial modernity was pursued by introducing a patriarchal structure where men seized power over women's sexuality.

Colonialism addressed African women's morality also through their gender roles. Domesticity was promoted as a method of "civilizing" women. Traditionally, African women worked in the field cultivating crops and processed diaries. Missionaries trained and supervised the "Jeanes" teachers- females home demonstrators. They were funded by colonial state during 1930s through 1970s- to train Zimbabwean women around the country on "modernizing" concepts of domesticity (Hendricksson, 1996).

It is needless to explain that these values according to contemporary measures are diametrically opposed not only to values upheld by current notion of "modernity" but also to the common sense of individual's rights and women's rights. What to underscore here is that what was perceived by colonial powers as immoral, backward, savage, and traditional among Africans was actually what the West came to declare as modernity, progress and women empowerment centuries later. This is evident in the celebration of the sexual revolution of the sixties of the twentieth century in the West and touting it as a decade of sexual revolution, women liberation, and progressive social movements. Many Marxists, for instance, analyzed the sexual revolution of the sixties as revolution against bourgeois identity which was forged centuries earlier around the confinement of sexuality. The anti-authoritarian and rebellious movements of the 1960s considered the reproductive suburban family and its morality of self-restraint and moral puritanism as a manifestation of class domination.

Henceforth, sexual liberation, was tied to revolutionary accomplishments. These accomplishments were: the change in the relationships between women and men, mainly 
those stirred by the emerging women's liberation movements. This led to females' increased presence in the public domains and personal independence concerning reproductive choices and sexual expression. Wasn't that the freedom made colonialists call African women shameless and urged colonialists' modernity to introduce patriarchal structure to restrain them?Wasn't that the public presence of African women colonial modernity fought in its civilizing mission by enforcing "domesticity"?

It is interesting to observe that the goals Europeans set to "modernize" African women were the confinements and backwardness the revolutionaries of the sixties set to overcome. The modern progressive practices accomplished in 1960s were the practices colonial powers fought in Africa and perceived as features of savageness and immorality. This leads us to construe that the "modern" and "civilized" promoted in Africa was nothing but the opposite of what colonial powers' cultural values and moral views were. The "modern" and "civilized" was not about an objective meaning; it was about passion and sentiment and not about rationality as modernity is claimed to be absolutely about.

\section{Clothing}

Another area on which African women's morality was addressed and controlled was the way they dressed. The colonial conquest created sociopolitical systems in which African people were forced to convert to Christianity and to wear Western styles of dress. Clothing "the natives" was a central focus of the colonial missionary project. In Africa, in Bechuanaland, a frontier region between colonial Botswana and South Africa, the process of moralization required dressing Africans in European clothes "to cover their nakedness" and control their bodies through new hygiene methods. Missionaries were pleased when Africans submitted to European clothing, seeing it as a sign of religious conversion in the new moral system of soul and body. Additionally, colonial agents often sent a message by dressing in full European outfit and touring in Africa; they wanted to dress "properly" to be viewed as evidence of Europeans' moral and cultural superiority.

This practice was indeed informed by the racist views which guided colonialism. Philip Setel, for example, has argued that nineteenth century travel narratives about Africa define "a conceptual domain in which health, illness and techniques of bodily display linked Africans to preconceived notions of race, moral status and savagery" (emphasis is mine)(Hendrickson, 1996: 193). That is to say colonial agents saw the revealing Africans' outfits and interpret them as signs of Africans' low morality. So the statement colonial agents were making by touring in Africa in European outfits was intended to " inspire" Africans to embrace "modernity" embodied in European covering clothing thereby, hopefully, elevate them in the ladder of morality.

Interestingly, "clothing the natives" was a task delivered in a number of formulas one of which is "hygiene" besides morality and respectability. But the fact that this task was tackled mainly by missionaries indicates its religio-moral motivation for which sexuality is a measure of propriety. In Zimbabwe, for example, the strong emphasis on hygienic training was led by missionaries where they pursued the making of Christian "civilized" African communities. Changes in appearance and habits of converts, particularly the wearing of European dress 
became essential symbol of what the missionaries wished to be a full socio-moral transformation of African life.

Yet, it is important to notice that it was not merely sexuality; it was rather women's sexuality. For example, in Clothing and Difference, Burke states that African women were the most exaggerated subjects to promote "civilized" manners. In many ways, she points out, "the imagined body of the colonial subject in Zimbabwe was first black but also crucially female...Zimbabwean women in both rural and urban communities were increasingly exposed to settler notions about...bodily propriety" (Hendrickson, 1996:195).

The excessive focus on African women's sexuality reflects the compromised social status of European women which projected its opposite on the African women, thereby labeling it "backward." That is, European women and sexuality was controlled by men in a patriarchal structure and Christian worldview which scandalized sexuality and scrutinized individuals with more emphasis on women's "body propriety" and demanded them to dress in all-covering outfits. Therefore, the dressing habits of African women signaled the opposite of the "civilized" European moral system and habits therefore, recieved the title "traditional" and "backward".

Accordingly, the campaigns carried out by colonial powers to improve women's morality and civilize them manifested, among other things, in the way they dressed. In Clothing and Difference James traces the substantial changes on clothing in South Africa over three generations, he states that little girls were "supposed to wear blouses to cover breasts." He also identifies the main features of clothing introduced by colonialism as: length of dress, headscarf with large piece of cloth and bangle, vest, knit shirt, overalls and a piece of cloth wrapped around the waist. In the same text, Moning analyzes the relation between identity and clothing; he describes the impact of Europeans on the Pedi of Sekhuneland's dress. He states that " most initiated girls nowadays wear long, gaily-colored cloths from their loin down to their feet covering the traditional clothing while very few women wear traditional hair-style, usually covering their heads with a head-cloth instead"(Hendrickson, 1996:39). Moning explains that if people adopt these Western clothes, "they are seen as treading one way path from tradition to modernity" (Hendrickson, 1996:39). It is obvious from the description of clothing above, specially the headscarf and the length of the dress, it was intended to fight the display of the revealed bodies of African women and to "improve their morality" according to colonial notions of modernity.

This feature of modernity, as perceived by colonial powers, is not only diametrically opposite but also antagonistic to the contemporary notions of modernity and progress especially regarding gender, sexuality and women liberation. That is especially true when we realize, for example, the recent uproar against females' headscarf in France. The members of French judicial system aver that the law advocates France's value of secular liberalism, basically what makes France "French," and many perceive females' headscarf, not as a religious and cultural belief but as resistance to modernity. It is interesting to note that this is the same headscarf, along with the lengthy dress and overalls, introduced a century earlier by colonialism as "modernizing" and civilizing" feature and to "improve African women's 
morality." This is a striking irony between two diagrammatically opposite features of modernity regarding women liberation in colonial context in Africa and in Western context in regards to the headscarf. It is important to briefly note here the fact that in both cases women's right to choice has been fundamentally compromised in a way mocks modernity's most celebrated ideals: freedom and individualism.

Moreover, some advocates of headscarf prohibition claim that it diminishes the boundaries between the public and the private. Scott for instance argues "the head scarf is tangible sign of intolerable difference.... It stands for everything that is thought to be wrong with Islam: porous boundaries between public and private and between politics and religion; the supposed degradation of female sexuality and subordination of women" (Najmabadi, 2006).

Interestingly, this was the same boundary colonial modernity completely removed when it instructed African women about how to dress to be moral and civilized. It was also the same boundary the British destroyed when they made marriage and women-men relationships a public matter by forging laws that condemn any practice in Africans' private lives that was not approved by the court and the church. It was also the same subordination of women in Africa by colonialists through introducing a patriarchal system in which men were assigned guardians of women's sexuality and custodians of females' morality. In addition, when missionaries joined forces with colonialism to introduce these modernizing features it had already canceled the religion-politics boundary. It was all about the differences that colonialism refused to tolerate and opted for corrosively altering their subjects' cultures, just as Scott now refuses to tolerate the "headscarf difference" in the statement above. All carried out in the name of modernity and civilization.

Another domain which colonial modernity addressed regarding morality and women's bodies was dance. Here I would like to extend the discussion about dress to dance where I highlight the concepts of women's body and nudity in relation to dance and modernity.

\section{Dance}

In "Cultural Anthropology and Human Challenge", Haviland discusses the deliberate changes made by the British during colonialism to alter their subjects' cultures in the name of improving their morality. The British, he explains, prohibited ritual dances because they were "erotic" and "immoral." They introduced them to British "quiet and composed" games to replace the erotic dancing and open sexuality that normally followed the harvests. Traditionally, this was the time when chiefs sought to augment their prestige by hosting festivities with provocative dancing along with chanting full of sexual insinuation. To British colonialists, cricket seemed a good way to end all of this in a way would encourage "conformity to civilized comportment in dress, religion, and sportsmanship" (Haviland, 2005:408-409).

This is another telling example of a notion of modernity that is completely opposite to the current notions where erotic dance and women's revealed bodies are considered strong features not only of modernity but women liberation and empowerment. Toepfer, for instance, in "Nudity and Modernity in German Dance 1910-1930," discusses the impulses within the 
German modern dance movement, in the first half of the twentieth century, which attempted to present the nude body as a sign of a modern and liberated identity. He explains that "the appearance of the nude dancing in Europe, was the discovery of modern relations between desire, the body, and the gaze" (emphasis is mine)(Toepfer, 1992). According to Toepfer, the use of nudity to signify the performance of modernity occurs at a time of quite unsystematic experimentation forging a modern attitude toward relations between desire and the body, yet, these relations are never remote from erotic significance.

This illustrates the shaky and complicated first steps of Europe toward current notions of modernity which were, essentially, cultural features that colonial Europe fought at its colonies centuries earlier. This is especially true when we realize the reference in Toepfer's discussion is to women. He states that "attitudes toward the modern nude, and especially female body (in dance) expose more complex and recessed attitudes toward modern, dance constructions or "performances "of sexual difference." Toepfer emphasizes the importance of this type of dance, in which females are exposed, as a strong sign of modernity. Toepfer's argument is to "use nudity in dance to equate "more modern" condition with the act of asserting a "more naked" identity." That is to say the female's nude body in dance equates a liberated empowered identity, that is, woman's liberated identity.

The fact that Europe was just "discovering" the "liberating" elements of the erotic dance which it prohibited in its colonies as indication of savagery and backwardness is illuminating. It begs the question again about the meaning of "modernity" and "tradition" or to be more specific the "modern and civilized" versus the "traditional and backward." How are they defined, by whom, and according to what premises. Seemingly, it is appealing, given the discussion so far, to say that the modern, or at least the way it is popularly used, is equal to the Western or the European. While this answer contains some truth, it is a partial truth. For an examination of some episodes of the history of dance within the West reveals an interesting pattern. To narrow down what is "modern" and and what are its conditions more specifically, in the rest of this section I would like to highlight experiences of some of those emerged within the West as art, or more specifically, dance icons.

In "African American Performance and Theater History" Elam and Krasner discuss the socio-cultural and political struggles that African American females dancers had to deal with in their careers. They highlight the stereotypes and racism that condemned the morality of African American females in general and dancers in particular. Elam and Krasner indicate that since "black women were mythologized as oversexed" and wedged between the needs to express their creativity and to obstruct the stereotypes, black female dancers were constantly under scrutiny for their "erotic" movement and pressed to choreograph according to the current codes of morality. That is why, they assert, Josephine Baker had to reject American morality and departs to Europe. Elam and Krasner narrate that when Baker arrived in Paris, unrestricted by Puritan morality, she fashioned the "Danse Sauvage" with the pattern of "exotic black." In Europe, Baker faced "primitivism" -as Elam and Krasner call it- no less racist but a repressed one.

Baker, however, was not the only black female dancer that struggled with the narratives of the 
oversexed immoral black woman. Aida Walker, for example, suffered contentiously from the "primitivism" in America and continued to modify her dance to suit the moral codes of the town she was visiting. Elam and Krasner point to the extreme difficulty under Jim Craw laws which imposed more racial restrictions on black female dancers urging Walker to restrain her sexual expression in dance (Elam and Krasner, 2001).

Obliviously, Baker and Walker, among others, were stigmatized by the same notions of savagery and backwardness projected on African women by European colonialists. It only takes watching the film that chronicles Baker's life to know the descriptions heavily loaded with the moralized racism about the "half-naked negro" dancer. The names and slurs casted on Josephine Baker's dance resembles the descriptions casted by Long and Ripley and other colonialists about the "shameless" and "oversexed" African women which reflected the sexual anxiety of male colonialists and their repressions.

However, to return back to the question about the meaning of modernity and tradition and the premises that generate them, it is evident that the answer that the modern is equivalent to the Western and European is not sufficient considering the cases of Baker and Walker. The narrative needs to exclude particular demographic within the West for it to be more specific. For if nudity and sexual dance was touted in a highly philosophical and aesthetic analysis offered in Toepfer's article as strong features of modernity and women empowerment in German dance, why did it not apply to African American female dancers? Instead, African American female dancers had to deal with different type of constraining socio-moral code. Just to be accepted as regular citizens of a "modern" society, they needed to conform to the bourgeois morality. That is made clear in Fannie Williams' statement written in the turn of the twentieth century that "showered with sexual and racial stereotypes, black women campaigned for respectability and moral authority....black women's grave responsibility is to maintain bourgeois respectability because the negro is learning that the things our women are doing come first in the lessons of citizenship" (Elam and Krasner, 2001:197).

It is understood that even the characters of the German female dancers Toepfer refers to in his article might had their share of stigma and condemnation given the bourgeois morality prevailing in the West at the time and the shaky steps it was taking toward "new features of modernity" and accepting them as liberating agents. Yet, they were not perceived as acting according to their inherent immorality and savagery based on their skin color like Baker and Walker were. In retrospective analysis about modernity and its features, African American female dancers, or people of African descent in general in the West despite their tremendous liberating contributions to social liberty, political rights, art and fashion in the West are never portrayed as liberating, "modernizing" or civilizing agents. Instead, they have always been associated with the "traditional", "backward" and "immoral." That is why I suggest excluding specific demographic within the West to be able to accurately describe what is "modern" as it is popularly used a fact that necessitates adding a racial dimension to its connotation.

\section{Conclusion}

It is obvious from the cases discussed above that in every case of encounter between the West and Africa, and the Other in general, the modern and civilized has always been what the West 
is. Being civilized meant to behave and dress like a European. The fixation on women's sexuality and considering it a measure of morality and propriety in Europe was projected on the rest to measure their level of civilization. Thus, since Africans and African women acted opposite to the Europeans in regard to sexuality and men-women relationship, they were considered lacking in civilization and described as traditional, and backward. Colonialists could not handle their sexual freedom and independence and posited them in the bottom of the ladder of civilization. Therefore, the intervention was to introduce patriarchal structure in which their sexuality was regulated and controlled the way it was in Europe. African women's public presence was addressed through heavy campaigns on domesticity. Their revealed body signaled their savagery, therefore, required instructing them about decency and introducing all-covering outfits including the long dress and the headscarf. Their ritual dances with its erotic movements and explicit sexual chants needed to be eradicated and replaced with "composed appropriate civilized" games.

However, when the West came to terms with the obsession with women's sexuality and its implications on gender-imbalanced roles in the 1960s of the twentieth century more than a century later, it realized the means to women liberation and empowerment. Henceforward, sexual freedom, revealed bodies, and erotic dance became potent features of civilization and modernity in the West. Curiously, that shift did not happen without projecting its opposite, which used to be Europe's past moral system, on the Other again. Hence, in illogical illusive way the Other continued to occupy the space of the uncivilized, traditional, and backward despite the fact that this Other was the original home of the new features of "modernity." The fact that these new features of modernity have been ever present in the Other, that is Africa, is ignored and overlooked thereby allowing for ahistorical narrative of civilization and modernity backed by mendacious epistemology where modernity is portrayed as one-way process stemming from one and only source, that is the West.

If the encounter of the West with Africans was about sameness and difference where the West recognizes itself against what it is not, then it would have been normal for Europe to define itself against its opposite. But this is not what we witness in the narratives of modernity and civilization. On the contrary, the West defines the rest, instead of itself, according to what the rest is not in correspondence with granting positive value to what the West is. In fact, "culture" seems to belong only to the rest while the West does not have "culture"; it has "modernity;" an exalted system aligned with science and philosophy; a higher construct beyond culture and above judgment.

Evidently, the meaning of modernity shifted from one thing to its total opposite as we have seen in the themes of women's morality without ever changing who is civilized and modern and who is not. The West has always been the custodian of civilization and the source of modernity thereby assigning modernity to a particular geographic region: Western Europe and North America. Yet, realizing the fact that certain demographic categories within the West have been excluded and ignored like the rest of the world in modernity narratives, it seems that modernity is not only assigned to a particular geographic region but also to a particular race and to skin color. 
A glance at the contradictory meanings modernity and civilization held over time would make it appealing to think that the meanings of modernity is inconsistent. However, this inconsistency is only an appearance because these meanings are only manifestations for the same kernel. For modernity or "civilization" have been consistent on the following:

Modernity is ethnocentric and coercive: during colonialism that was clear on rejecting the the difference of the subjects as lacking in morality and modernity and exerting tremendous efforts to assimilate them through imposing patriarchal structure, all-covering dress and headscarf, and "moral" dance. This coercion continues today, in the name of modernity as well, in the "headscarf" issue in France as one example. The contemporary criticism mounted on Muslims' communities in the West, and some other cultural communities, for resisting assimilation is another example for modernity's ethnocentricity and coercion. The pattern of coercion is also manifested in some developmental paradigms where individualism, for example, along with other Western cultural values, are prescribed as cures for the "Third World's" ills without which it would not make it to modernity.

Modernity is assigned geographic home: In modernity narratives, the West has always been the modern in an illogical way that suspends modernity in a historical vacuum in which historical facts and events about the West and the rest, their interactions, and the shifts on their values and moralities are ignored. This dehistoricization resulted in a mythologized views about geographic regions where the West eternally assumed the position of the modern and other geographic regions have been and will always be traditional.

Modernity is assigned to skin color: That was clear in categorizing colonial subjects according to the combination of skin color and "failure" to measure up to European moral yardstick. This combination has a continuation in the home of "modernity" in the case of African Americans and African diaspora where they are never identified with modernity despite their tremendous contribution to social liberty, political freedoms, and art generally but particularly in regard to women morality. This was evident in the case of Baker and Walker in contrast to the characters discussed in Toepfer's article as liberating agents during the "discovering" of modernity and women empowerment through nudity and dance by Europe in early twentieth century. A candid look into the history of African diaspora would recognize its liberating impact on the West. It only takes intellectual integrity to realize the connection between contemporary features of modernity and the descriptions of Africans' morality present in colonial reports.

Modernity is defined according to what the West is and the Other is not: that is evident in the diametrically opposite meanings modernity connoted overtime without changing who is holding it. And here I would like to make a triangulation to explicate the complex contours in meaning(s) of modernity denoting the relation of the West with the rest. For instance, Mohammed Quttob's criticism of nudity and sexual freedom in the West has been cited frequently to indicate how hopeless Muslims are to ever be modern. Yet, the condemnation of African women's sexual freedom by Europeans are not mentioned to indicate backwardness of Europeans. Neither were the slurs and prosecutions of African American female dancers by the state and the society perceived as "traditional" or/and backward. Additionally, the fact 
that the West did not take issue with women's practices or dress habits in the Middle East during colonialism the same way it did with Africans seem to suggest that they (the West and the Middle East) had features in common. That is, the West condoned restrictions applied on women in the Middle East at the time. Yet, the West still labeled the Middle East, along with Africans, as traditional and backward in Orientalist paradigm. Thus, in a triangulation of the West, Africa, and the Middle East, the West has always occupied -and continues to occupythe modernizing role toward the Other despite the cultural differences of these regions.

Interestingly, in the current context, Africans are never described as "modern" in the current literature about modernity despite the presence of the cultural features regarding women freedom. The same practices described as signs of liberty in the West perceived differently in Africa. Africans are continued to be recognized as backward, this time however, based on different reasons that relate to economics, family structure and individualism, technology, etc. Muslims and the Islamic World, on other hand, are given the label of the traditional and backward primarily because of cultural traits concerning women freedom, dress and sexuality. The West always found a way to relegate the Other. Depending on what the socio-moral and technological features of the West are, modernity is defined and, correspondingly, the opposite of that definition is granted to others.

In short, rather than having an objective neutral connotations of advancement and progress, modernity is fundamentally biased. It is not associated with progressive humanist values based on rationality as it is proposed to be. Rather, it is associated with exclusive geographio-racial moral system based on sentiment and passion. It is dehistoricized by delinking it from historical facts and contexts ignoring the shifts on values and moral systems and denying the "others" contributions. This makes modernity a fluid and nebulous concept that has been constantly adjusted to be equated with what the Western is while its opposite, the traditional, has always been equated with the Other in which Africans are the farthest from modernity regardless of historical facts.

\section{References}

Barker, C. (2005). Cultural Studies: Theory and Practice. London: Sage.

Chanock, M. (1998). Law Custom and Social Order: The Colonial Expereince in Malawi and Zimbabwe. Portsmouth: Heinemann.

Elam, J., \& Krasner, D. (2001). African American Performance and Theater History Reader. US. Oxford University Press.

Fashion and Clothing Encyclopedia: Colonialism and Imperialism. [Online] Available: http://angelasancartier.net/colonialism-and-imperialism

Haviland, P., \& Walrath, M. (2005). Cultural Anthropology: The Human Challenge. Canada: Thomson Learning Inc.

Hendrickson, H. (1996). Clothing and Difference. North Carolina: Duke University Press.

Najmabadi, A. (2006). Gender and Secularism of Modernity: How Can a Muslim Woman Be 
French? Feminist Studies, 32(2), 239-255. https://doi.org/10.2307/20459085

Sexuality and Modernity: the Sexual Revolution of the 60s. [Online] Available: http://www.isis.aust.com/stephan/writings/sexuality/revo.htm

Stoler, A. L. (1996). Race and the Education of Desire. North Carolina: Duke Univerity Press.

Toepfer, K. (1992). Nudity and Modernity in German Dance, 1910-30. Journal of the History of Sexuality, 3(1), 58-108.

Young, J. C. R. (1995). Colonial Desire: Hybridity in Theories, Culture and Race. London Routledge.

\section{Copyright Disclaimer}

Copyright reserved by the author(s).

This article is an open-access article distributed under the terms and conditions of the Creative Commons Attribution license (http://creativecommons.org/licenses/by/3.0/). 